\title{
ARTIGOS
}

\section{INVESTIGATION OF THE RESPONSE TO THE ENTEROBACTERIAL COMMON ANTIGEN AFTER TYPHOID VACCINATION}

\author{
Arlete M. Milhomem ${ }^{1}$ and Ítalo Suassuna ${ }^{2}$
}

\begin{abstract}
Antibodies against the Salmonella typhi enterobacterial common antigen (ECA) and the $\mathrm{O}$ and $\mathrm{H}$ antigens were investigated in sera from healthy male subjects who had been previously vaccinated with the typhoid vaccine. No serological response to ECA was observed. Sera from subjects not previously vaccinated presented titers of ECA hemagglutinins which quantitatively were related to the presence of $H$ titers, but not to $O$ agglutinins but with no statistical significance. The results are discussed in relation to the possible protective immunological mechanisms in typhoid fever.
\end{abstract}

Key words: Typhoid fever. Vaccine. Salmonella typhi. Enterobacterial common antigen. $\mathrm{O}$ and $\mathrm{H}$ antigens.

Although the spread of typhoid fever has been generally controlled by environmental sanitation, vaccination is the method used for controlling this disease in many parts of the underdeveloped world.

Immunization by subcutaneous inoculation with inactivated Salmonella typhi has been used since the last century ${ }^{19}$ and interest continues regarding this procedure ${ }^{30}$.

The lack of an experimental animal model to study $S$. typhi, an organism pathogenic only for man, has been accepted as the reason for discussion about virulence and immunity mechanisms in man. Data from parallel animal models has led to faulty conclusions in relation with the observed facts in $\operatorname{man}^{19} 20$. In spite of the importance ascribed to many antigens in animal studies 121027 their role in human immunity remains to be ascertained.

Both the mechanisms responsible for typhoid immunity and the immunogens that give this protection have not been defined so far $^{20}$. Several bacterial components are known since the beginning of the century: flagellar $(\mathrm{H})$ antigens, lipopolysaccharide containing somatic $(\mathrm{O})$ antigens, rough lipopolysaccharides (R) antigens, proteins, ribossomal fractions capsular (Vi) antigen, fimbriae and the enterobacterial common antigen (ECA) of Kunin ${ }^{13}$. The value of the so called virulence antigen $(\mathrm{Vi})$ has been challenged ${ }^{14}$. ECA is probable present on the outer surface of the bacteria and it is believed to be involved in reactions of the bacteria with their animal hosts. The role of this antigen in infections and immunity related

1. Instituto de Microbiologia, Universidade Federal do Rio de Janeiro, RJ, Brasil.

2. Faculdade de Ciências Médicas, Universidade do Estado do Rio de Janeiro, RJ, Brasil.

Recebido para publicação em 10/3/86. to the enterobacteriaceae, together with other antigens, has been investigated in experimental animal models 16 .

McLaughin \& Domingue ${ }^{18}$ have suggested the use of this antigen for human immunization, since the ECA antigen has no toxicity, gave good humoral response in human volunteers ${ }^{11}$ and protection was observed in some experimental animal models ${ }^{6}$. This possibility was also considered by other authors 15 .

The possibility that ECA, present in the conventional typhoid vaccine, would share immunogenic properties with other known antigens, with a resulting antibody response, was examined, looking as a corollary for its significance in the human immune state in the enterobacterial diseases.

\section{MATERIAL AND METHODS}

Bacterial strains - Smooth strains of Salmonella typhi (Ty 2 and TH 901 Felix), Salmonella paratyphi A, Salmonella paratyphi B and Escherichia coli (014), were available as stock cultures at the Culture Collection of the former Enterobacterial Laboratory, Instituto de Microbiologia, Universidade Federal do Rio de Janeiro (Collection n. 313, the World Directory of Collection Cultures of Microorganisms). The Salmonella typhimurium strain was kindly suplied by Dr. Gerald Domingue, Tulane University, New Orleans, USA. The standard strains of $S$. typhi (TH 901 and Ty 2 Felix) and $S$. paratyphi $\mathrm{A}$ had been obtained from the Public Health Laboratory Service, London, and the $S$. paratyphi B and E. coli (014: K 7: NH) from the Center for Disease Control (CDC) Atlanta, Georgia, USA.

Antityphoid vaccination-The vaccine employed by the Brazilian Army contained $10^{9}$ heat killed bacterial cells per milliliter of $S$. typhi $\mathrm{Ty}^{2}$ and 
Milhomem AM, Suassuna I. Investigation of the response to the enterobacterial common antigen after typhoid vaccination. Revista da Sociedade Brasileira de Medicina Tropical 20: 7-12, Jan-Mar, 1987.

was preserved with 0.5 per cent phenol. Two doses were administrated to each of 49 healthy male recruits without a known history of previous vaccination. The first dose corresponded to $0.5 \mathrm{ml}$ and the second to $1.0 \mathrm{ml}$ given by the subcutaneous route.

Agglutinating flagellar antigens - The antigens were prepared as described by Pessoa \& Suassuna ${ }^{23}$ from the strains of $S$. typhi, $S$. paratyphi A and, $S$. paratyphi $\mathrm{B}$.

Agglutinating somatic antigens - The somatic antigens were prepared as described by Edwards \& Ewing ${ }^{9}$ from the corresponding strains employed for the flagellar antigens.

Common antigen extract - ECA was prepared by the method of Suzuki, Gorzynski \& Neter ${ }^{26}$. ECA was obtained from $S$. typhi and S. typhimurium. Both preparations were able to sensitize rabbit red blood cells (RBC) and showed good specificity. $S$. typhimurium extracts were used for animal inoculation in order to obtain the animal sera for titration of ECA, and extracts of $E$. coli 014 and $S$. typhimurium were used to evaluate the specificity of the reactions by hemagglutination and hemagglutination inhibition ${ }^{28}$. The workable dilution for the common antigen obtained from $S$. typhi was 1:6 and for S. typhimurium the sensitising capacity reached 1:30. The 1:15 dilution of $S$. typhimurium was then used throughout as the sensitizing solution for $\mathrm{RBC}$.

Antisera-Antisera against ECA were obtained in rabbits (adults, New Zealand White) weighing 2.5 to $3.0 \mathrm{~kg}$ as described by Domingue et al ${ }^{6}$. Immunization was made by the intravenous route on alternate days as follows: three injections of $0.5 \mathrm{ml}$ doses of $\mathrm{S}$. typhimurium heat-killed supernatant to prime the response to ECA, followed by two injections of $5.0 \mathrm{ml}$ doses of the ethanol soluble ECA derived from the same strain of S. typhimurium. Serum samples were obtained before immunization, and seven days after the serial injections.

Rabbit antisera against the somatic and flagellar antigens of $S$. typhi, S. paratyphi A and S. paratyphi $B$, prepared in accordance with the methods of Edwards and Ewing ${ }^{9}$ were kindly supplied by Dr. Ivone R. Suassuna.

Antibody titrations - The standard Widal agglutination test was used with $\mathrm{O}$ and $\mathrm{H}$ bacterial suspensions of $S$. typhi, S. paratyphi A and $S$. paratyphi B, starting with the 1:20 dilution with subsequent twofold increases up to 1:1280. The reciprocal of the highest dilution showing complete agglutination of the bacterial suspension was taken as the titer of the serum.

Passive hemagglutination with fresh human $\mathrm{O}$, $\mathrm{Rh}$ negative, red blood cells was performed as described by Whang $\&$ Neter 28 .

For the hemagglutination tests $0.2 \mathrm{ml}$ of the ECA sensitized RBC suspension were added to $0.2 \mathrm{ml}$ of serum in serial twofold dilutions. The mixture was incubated at $37^{\circ} \mathrm{C}$ for $30 \mathrm{~min}$ in water bath. and the resulting hemagglutination was macroscopically read after centrifugation at $1300 \mathrm{~g}$ for $3 \mathrm{~min}$.

Pearson's correlation tests were used for statistical evaluation of results ${ }^{4}$.

\section{RESULTS}

The results obtained by serological studies of agglutinins against the flagellar and somatic antigens of $S$. typhi in individuals before typhoid raccination (Table 1) show that the normal level of agglutinins was lower than 80 , although in one occasion this titer was observed against the $\mathrm{H}$ antigen. Also, the percentage of positive results was higher for the $\mathrm{H}$ antigen.

Table 1 -Agglutinin titers for somatic and flagellar antigens respectively of Salmonella typhi (TO and TH), S. paratyphi $\mathrm{A}(A O$ and $A H)$ and $\mathbf{S}$. paratyphi $\mathbf{B}(B O$ and $B H)$ in sera from 49 individuals before typhoid vaccination.

Titers (*)

\begin{tabular}{ccccccccccccc}
\cline { 2 - 11 } Antigens & \multicolumn{2}{c}{ negative } & \multicolumn{2}{c}{ positive } & \multicolumn{2}{c}{20} & \multicolumn{2}{c}{40} & \multicolumn{2}{c}{80} \\
\cline { 2 - 10 } & $N^{\circ}$ & $(\%)$ & $N^{\circ}$ & $(\%)$ & $N$. & $(\%)$ & $N^{\circ}$ & $(\%)$ & $N .0$ & $(\%)$ \\
\hline TH & 25 & $(51.0)$ & 24 & $(49.0)$ & 15 & $(30.6)$ & 8 & $(16.6)$ & 1 & $(2.0)$ \\
TO & 48 & $(98.0)$ & 1 & $(2.0)$ & 1 & $(2.0)$ & - & - & - & - \\
AH & 49 & $(100.0)$ & - & - & - & - & - & - & - & - \\
AO & 48 & $(98.0)$ & 1 & $(2.0)$ & - & - & 1 & $(2.0)$ & - & - \\
BH & 49 & $(100.0)$ & - & - & - & - & - & - & - & - \\
BO & 49 & $(100.0)$ & - & - & - & - & - & - & - & - \\
\hline
\end{tabular}

(*) reciprocal of dilution 
Milhomem AM, Suassuna I. Investigation of the response to the enterobacterial common antigen after typhoid vaccination. Revista da Sociedade Brasileira de Medicina Tropicai 20: 7-12, Jan-Mar, 1987.

Nine days after the first dose of vaccine, the agglutinin titer for these same antigens showed, as expected, an elevation, specially for the $\mathrm{H}$ agglutinins.

Consequent to the first dose of the vaccine one could observe an elevation of positivity from 2 to $10.2 \%$ in the case of $S$. paratyphi A somatic antigen, and from zero to $22.4 \%$ in the case of S. paratyphi B (Table 2). After the second dose of the vaccine, analogous results were obtained (Table 3 ). On all occasions the maximum level of agglutinins for those antigens was 1:40. As expected, the titer for the flagellar agglutinins remained unaltered and were not referred to on Tables 2 and 3.
Table 3 presents the agglutinin titration for these antigens twelve days after the second dose of vaccine. The results show a small elevation in the percentage of positive reactions and on the level of agglutinins for the $\mathrm{H}$ antigen.

As expressed on Table 1 agglutinin against the somatic and flagellar antigens of $S$. paratyphi $\mathrm{A}$ and $S$. paratyphi B were studied in the sera of individuals before vaccination. Results were negative for all antigens, except in one case where the $S$. paratyphi A somatic antigen showed an agglutination titer of 40 .

The levels of antibodies against ECA in the 49 individuals studied can be seen in Table 4. The sera of

Table 2 - Agglutinin titers for somatic and flagellar antigens of Salmonella typhi and somatic antigens of $\mathbf{S}$. paratyphi $\mathrm{A}$ and $\mathrm{S}$. paratyphi $\mathrm{B}$ in the sera from 49 individuals 9 days after the first dose of anti-typhoid vaccine.

\begin{tabular}{|c|c|c|c|c|c|c|c|c|c|c|c|c|c|c|c|c|}
\hline \multirow{3}{*}{ Antigens (**) } & \multicolumn{16}{|c|}{ Titers (*) } \\
\hline & & $\begin{array}{l}\text { Total } \\
\text { Tegative }\end{array}$ & & $\begin{array}{l}\text { Total } \\
\text { ositive }\end{array}$ & & 20 & & 40 & & 80 & & 160 & & 320 & & 640 \\
\hline & No & $(\%)$ & $N^{o}$ & $(\%)$ & No & $(\%)$ & $N .^{\circ}$ & $(\%)$ & $N^{\circ}$ & $(\%)$ & $N o$ & $(\%)$ & $N o$ & (\%) & $N^{\circ}$ & $(\%)$ \\
\hline TH & 2 & $(4.1)$ & 47 & $(95.9)$ & 2 & $(4.1)$ & 9 & (18.4) & 15 & $(30.6)$ & 9 & $(18.4)$ & 11 & $(22.4)$ & 1 & $(2.0)$ \\
\hline TO & 17 & $(34.7)$ & 32 & $(65.3)$ & 15 & $(30.7)$ & 8 & (16.3) & 6 & (12.2) & 3 & ( 6.1$)$ & - & - & - & - \\
\hline AO & 44 & $(89.8)$ & 5 & $(10.2)$ & 4 & $(8.2)$ & 1 & $(2.0)$ & - & - & - & - & - & - & - & - \\
\hline BO & 38 & $(77.6)$ & 11 & $(22.4)$ & 6 & $(12.2)$ & 5 & $(10.2)$ & - & - & - & - & - & - & - & - \\
\hline
\end{tabular}

(*) reciprocal of dilution

(**) see Table 1 .

Table 3 - Agglutinin titers for somatic and flagellar antigens of Salmonella typhi and somatic antigens of S. paratyphi $\mathbf{A}$ and $\mathbf{S}$. paratyphi $\mathbf{B}$ in the sera from 49 individuals 12 days after the second dose of typhoid vaccine.

Titers (*)

\begin{tabular}{|c|c|c|c|c|c|c|c|c|c|c|c|c|c|c|c|c|}
\hline \multirow[t]{2}{*}{ Antigens (**) } & \multicolumn{2}{|c|}{$\begin{array}{c}\text { Total } \\
\text { Negative }\end{array}$} & \multicolumn{2}{|c|}{$\begin{array}{c}\text { Total } \\
\text { Positive }\end{array}$} & \multicolumn{2}{|r|}{20} & \multicolumn{2}{|r|}{40} & \multicolumn{2}{|r|}{80} & \multicolumn{2}{|r|}{160} & \multicolumn{2}{|r|}{320} & \multicolumn{2}{|r|}{640} \\
\hline & $N o$ & $(\%)$ & $N i^{o}$ & $(\%)$ & $N^{o}$ & $(\%)$ & $N .^{\circ}$ & $(\%)$ & $N .^{\circ}$ & $(\%)$ & No & $(\%)$ & No & $(\%)$ & $N o$ & $(\%)$ \\
\hline $\mathrm{TH}$ & - & - & 49 & $(100.0)$ & 1 & $(2.0)$ & 6 & $(12.6)$ & 10 & $(20.4)$ & 13 & $(26.6)$ & 16 & $(32.7)$ & 3 & $(6.1)$ \\
\hline TO & 8 & (16.3) & 41 & ( 83.7$)$ & 15 & $(30.6)$ & 12 & (24.5) & 13 & $(26.6)$ & 1 & $(2.0)$ & - & - & - & - \\
\hline $\mathrm{AO}$ & 44 & $(89.8)$ & 5 & $(10.2)$ & 4 & $(8.2)$ & 1 & $(2.0)$ & - & - & - & - & - & - & - & - \\
\hline BO & 37 & $(75.5)$ & 12 & ( 24.5) & 8 & (16.3) & 4 & $(8.2)$ & - & - & - & $\ldots$ & - & - & - & - \\
\hline
\end{tabular}


Milhomem AM, Suassuna I. Investigation of the response to the enterobacterial common antigen after typhoid vaccination. Revista da Sociedade Brasileira de Medicina Tropical 20: 7-12, Jan-Mar, 1987.

Table 4 - Frequency of different patterns of variations of antibodies to the enterobacterial common antigen detected by hemagglutination in sera from 49 individuals, before and after tiphoid vaccination.

\begin{tabular}{cccc}
\hline & \multicolumn{3}{c}{ Reciprocal of senum dilution } \\
\cline { 2 - 4 } Frequency & $\begin{array}{c}\text { Before } \\
\text { vaccination }\end{array}$ & $\begin{array}{c}\text { After first } \\
\text { (9 days) }\end{array}$ & $\begin{array}{c}\text { After } 2^{\text {nd }} \text { dose } \\
\text { of vaccine } \\
(12 \text { days })\end{array}$ \\
\hline 5 & $10^{*}$ & 10 & 10 \\
5 & 10 & 10 & 10 \\
1 & 10 & 20 & 20 \\
11 & 20 & 20 & 20 \\
1 & 20 & 40 & 40 \\
20 & 40 & 40 & 40 \\
6 & 80 & 80 & 80 \\
\hline
\end{tabular}

* Lowest dilution employed.

five individuals showed titers lower than 10 (the lowest investigated) and the remaining had titers equal or above the this dilution. The highest titer observed was 80 . After vaccination the results did not change, except in two cases, but in these, the elevation was not significant taking into account the experimental method (difference of one dilution) following the first dose of the vaccine.

Data concerning the hemagglutinating titers for the ECA, S. typhi $\mathrm{O}$ and $\mathrm{H}$ agglutinins obtained before vaccination are summarized in Table 5. By conside-

Table 5-Patterns of distribution and frequency of hemagglutination titers for ECA and titers for the $H$ and $O$ antigens of $\mathrm{S}$. typhi before anti-typhoid vaccination.

\begin{tabular}{|c|c|c|c|}
\hline \multicolumn{3}{|c|}{ Patterns of Antigen Titers } & \multirow{2}{*}{ Frequency } \\
\hline$E C A^{*}$ & $T H^{* *}$ & TO** & \\
\hline 80 & 20 & - & 4 \\
\hline 80 & - & - & 2 \\
\hline 40 & 80 & $\ldots$ & 1 \\
\hline 40 & 40 & - & 1 \\
\hline 40 & 20 & - & 8 \\
\hline 40 & - & - & 10 \\
\hline 20 & 40 & 20 & 1 \\
\hline 20 & 40 & - & 2 \\
\hline 20 & 20 & - & 2 \\
\hline 20 & - & - & 6 \\
\hline 10 & 40 & - & 2 \\
\hline 10 & 20 & - & 1 \\
\hline 10 & - & & 3 \\
\hline- & 40 & - & 2 \\
\hline- & - & - & 4 \\
\hline
\end{tabular}

* Lowest dilution $1 / 10$

* Lowest dilution $1 / 20$ ring the 1:20 dilution (the lowest employed for the detection of agglutinins), these results represent respectively for the $\mathrm{H}, \mathrm{O}$ and ECA antigens a percentage of $24.5,2.0$ and 30.6. The 1:40 dilution was observed with the ECA and $\mathrm{H}$ antigens only, with a frequency of 40.8 and 16.4 respectively. The same occurred in relation to the 1:80 dilution, which presented a frequency of positivity of $12.2 \%$ for the ECA antigen and $2.0 \%$ for the $\mathrm{H}$ antigen.

\section{DISCUSSION}

In Brazil typhoid fever is usually an endemic disease with occasional epidemic outbursts.

The results of titration of antibodies in the sera of individuals before typhoid immunization indicate that the frequency and the titer of antibodies to S. typhi $\mathrm{H}$ antigen are similar to those obtained in typhoid endemic regions of other countries ${ }^{24}$ as well as with those available for other areas of Brazil25.

Concerning the $\mathrm{O}$ antigen, the present results were lower than those obtained in endemic areas. This is in accordance with the notion that the response to specific stimulation with the somatic antigen is more transient than that to the flagellar antigen.

The results obtained after typhoid vaccination showed, as expected, a marked elevation in the frequency and titers of agglutinins. specially those against the antigens recognized as constituents of the vaccine $(09,012$ and $H d)$. Such results do not diverge from those obtained ten years ago 25 in a population of 1022 individuals living in Rio de Janeiro, 512 of which were military personnel with a history of annual vaccination and the others with a history of vaccination three years prior to the study. This emphasizes the influence of vaccination on the normal levels of agglutinins for the antigens present in the vaccine.

From the present results the normal antibody levels for ECA coexisted with titers to the $\mathrm{H}$ agglutinins of $S$. typhi, rather than with $\mathrm{O}$ agglutinins with no statistical significance (linear and exponential correlations).

Attemtps to evaluate the potency of the vaccine by the humoral response against the somatic, flagellar and $\mathrm{Vi}$ antigens have been unsuccessful ${ }^{20}$. Results showing that the flagellar antibody titer in typhoid patients sera provided a more reliable aid toward diagnosis than the somatic antibody titer have been reported, although the value of the Widal test in diagnosis was limited 7 . The role of $\mathrm{H}$ agglutinins in protection against typhoid fever has been denied by various authors as reviewed ${ }^{25}$ but the detection of these agglutinins in the sera of vaccinated individuals. specially those observed in field studies, seems to imply that the immunogenicity of this antigen corre- 
Milhomem AM, Suassuna I. Investigation of the response to the enterobacterial common antigen after typhoid vaccination. Revista da Sociedade Brasileira de Medicina Tropical 20: 7-12, Jan-Mar, 1987.

lated best with protection obtained in men. Beumer ${ }^{3}$ has suggested that in man, protection, might be mediated by antibodies against one or more bacterial antigens preserved in the same conditions as the $\mathrm{H}$ antigen, while Edwards et al $l^{8}$ believed that unidentified serum factors might be involved.

In the present experience typhoid vaccination did not induce antibodies against the ECA antigen. Such unsatisfactory humoral response do not exclude, however, participation of the ECA antigen in the protective in the mechanisms involved in the anti-typhoid immunization. It has been also reported that the typhoid vaccine, although non immunogenic for ECA, when inoculated in rabbits, primed the animal for a rapid secondary response to the purified antigen 22,29 . It was not reported either in animals or men whether the vaccine prepares them for a rapid humoral response to ECA. If this response occurs in man, it might be responsible for a partial inactivation of an infective dose. Some investigators feel that inactivation of this kind is responsible for the limited efficiency of the killed vaccines 5 .

The antigens involved in anti-typhoid protection were not defined. The greater exposure of ECA on the surface of rough mutants in relation to the smooth forms ${ }^{17}$, as well as the fact that, when coupled with Freund's complete adjuvant, delayed hypersensitivity phenomena are induced in guinea pigs ${ }^{21}$ warrant further investigation of the role of this antigen in the protection mechanisms involved in systemic enteric infections.

We wish to emphasise that the actual chemical and immunochemical nature of ECA is controversial which constitutes a limiting factor for the study of its biological activities ${ }^{20}$, and justifies Gorzynski's statement that prior to this antigen being employed as an immunogen, various questions concerning its biological activity must be answered ${ }^{12}$.

\section{RESUMO}

Anticorpos contra o antígeno comum de enterobactérias (ECA) bem como contra os antigenos somáticos $(O)$ e flagelar $(H)$ de Salmonella typhi foram investigados no soro de recrutas do sexo masculino, após a vacinação. Não foi detectada resposta humoral para ECA. Os soros obtidos antes da vacinação mostraram hemaglutininas para ECA acompanhando a presença de aglutininas para o antigeno $H$, ao contrário do que se observou em relação ao antígeno $O$. Discutem-se os resultados quanto ao possivel mecanismo da imunoproteção da febre tufoide.

Palavras chaves: Febre tifóide. Vacinação. Antígenos comuns de enterobactérias e $\mathrm{O}$ e $\mathrm{H}$ de Salmonella typhi.

\section{REFERENCES}

1. Arkwright $\mathbf{J A}$. The value of different kinds of antigen in prophylactic "enteric" vaccines. Journal of Pathology and Bacteriology 30:345-364, 1927.

2. Barber C, Eylan E. Behaviour of salmonellae non-pathogenic for mice. I. Neutralization of their toxicities by induced antiprotein antibodies. Zentralblatt fur Bakteriologie und Parasitenkund Infektionskrankheiten und $\mathrm{Hy}-$ giene. Abteilung Originale Reihe A 237:213-221, 1977.

3. Beumer J. Les vaccins antibacteriens: des microbes vivants aux antigène purifiés. Bulletin de l'Institute Pasteur 72:35-48, 1974.

4. Berquó ES, Souza JMP, Gotlieb SLD. Bioestatistica. Editora Pedagógica e Universitária Ltda. S. Paulo, 1980.

5. Colins FM. Mechanisms in antimicrobial immunity. Journal of the Reticuloendothelial Society 10:58-99, 1971.

6. Domingue GJ, Sahli A, Rountree C, Little W. Prevention of experimental hematogenous and retrograde pyelonephritis by antibodies against enterobacterial common antigen. Infection and Immunity 2:175-182, 1970.

? Doshi N, Taylor AG. Comparison of the Vi indirect fluorescent antibody test with the Widal agglutination method in the serodiagnosis of typhoid fever. Journal of Clinical Pathology 37:805-808, 1984.

8. Edwards EA, Johnson DP, Pierce WE, Peckinpaugh RO. Reactions and sorologic responses to monovalent acetone-inactivated typhoid vaccine and heat-killed TAB when given by jet injection. Bulletin of the World Health Organization 51:501-505, 1974.

9. Edwards PR, Ewing WH. Identification of Enterobacteriaceae. $3^{\text {rd }}$ ed. Burgess Publishing Co. Minneapolis, Minessota, 1972.

10. Felix A, Pitt RM. A new antigen of $B$. typhosus. Its relation to virulence and to active and passive immunization. Lancet 2:186-191, 1934.

11. Gorzynski EA, van Oss CJ, Ambrus JL, Neter E. The hemagglutinin response of human subjects to common enterobacterial antigen. Infection and Immunity 5:625626, 1972.

12. Gorzynski EA. Cross-reactivity between mouse tissue and enterobacterial common antigen (CA). Military Medicine 141:610-612, 1976.

13. Kunin CM, Beard MV, Halmaguy NE. Evidence for a common hapten associated with endotoxin fraction of Escherichia coli and other Enterobacteriaceae. Proceedings of the Society for Experimental Biology and Medicine 111:160-166, 1962.

14. Levine MM, Kaper JB, Black RE, Clements Ml. New knowledge on pathogenesis of bacterial enteric infections as applied to vaccine development. Microbiology Reviews 47:510-550, 1985.

15. Lugowski C, Kulakowska M, Romanowska E. Enterobacterial common antigen-tetanus toxoide conjugate as immunogen. Infection and Immunity 42:1086-1091, 1983.

16. Mäkela PH, Mayer H. Enterobacterial common antigen. Bacteriological Reviews 40:591-632, 1976.

17. Marx A, Petcovici M, Nacescu N, Mayer H, Schmidt G. Demonstration of enterobacterial common antigen by bacterial agglutination. Infection and Immunity 18:563567, 1977. 
Milhomem AM, Suassuna I. Investigation of the response to the enterobacterial common antigen after typhoid vaccination. Revista da Sociedade Brasileira de Medicina Tropical 20: 7-12, Jan-Mar, 1987

18. McLaughlin JC, Domingue GL. The immunologic role of the ethanol-soluble enterobacterial common antigen versus experimental renal infection. Immunological Communications 3: 51-75, 1974.

19. Milhomem AM, Suassuna I. A imunidade na febre tifóide. I. A vacinação antitifóidica de Wright, 1896 a 1979. Memórias do Instituto Oswaldo Cruz 77:93-120, 1982.

20. Milhomem AM, Suassuna I. A imunidade na febre tifóide. II. Antigenos e resposta imune nas salmoneloses sistêmicas. Memórias do Instituto Oswaldo Cruz 77:453$483,1982$.

21. Morgenstern MA, Gorzynski EA. Immune response of guinea-pigs to common enterobacterial antigen. Immunological Communications 2:495-506, 1973.

22. Neter $E$, Whang HY, Luderitz O, Westphal O. Immunological priming without production of circulating bacterial antibodies conditioned by endotoxin and its lipoid $\mathrm{A}$ component, Nature 212:420-421, 1966.

23. Pessôa MHR, Suassuna I. Relação de hemaglutinação passiva e aglutinação bacteriana: influência da natureza do antigeno, classe de imunoglobulinas e seu emprego. Revista Brasileira de Patologia Clínica 16:12-17, 1980.

24. Polish Typhoid Committee. Evaluation of typhoid vaccines in the laboratory and in controlled field trial in Poland
(Preliminary report). Bulletin of the World Health Organization 32:15-27, 1965.

25. Suassuna I, Nogueira ES, Fagundes CF. Títulos significativos da reação de Widal para o diagnóstico de salmoneloses no Estado da Guanabara. Revista Médica da Aeronáutica 1-2:123-130, 1970.

26. Suzuki T, Gorzynski EA, Neter E. Separation by ethanol of common and somatic antigens of Enterobacteriaceae. Journal of Bacteriology 88:1240-1243, 1964.

27. Venneman MR. Purification of immunologically active ribonucleic acid preparations of Salmonella typhimurium: molecular-sieve and anion-exchange chromatography. Infection and Immunity 5:269-282, 1972.

28. Whang HY, Neter E. Immunological studies of heterogenetic enterobacterial antigen (Kunin). Journal of Bacteriology 84:1245-1250, 1962.

29. Whang HY, Neter E. Further studies on effect of endotoxin on antibody response of rabbit to common antigen of Enterobacteriaceae. Journal of Immunology 98:948$957,1967$.

30. Woodward WE. Volunteer studies of typhoid fever and vaccines. Transactions of the Royal Society of Tropical Medicine and Hygiene 74:553-556, 1980. 